\title{
Teachers as Designers of Technology-Enhanced Outdoor Inquiry
}

\author{
Keren Sarah Levy \\ Technion Institute \\ of Technology, \\ Haifa, Israel
}

\author{
Yael Kali \\ University of Haifa, \\ Haifa, Israel
}

\author{
Tali Tal \\ Technion Institute \\ of Technology, \\ Haifa, Israel
}

\section{kerenl@campus.technion.ac.il yael.kali@edtech.haifa.ac.il rtal@ed.technion.ac.il}

\begin{abstract}
Implementing inquiry in the outdoors introduces many challenges for teachers, some of which can be dealt with using mobile technologies. For productive use of these technologies, teachers should be provided with the opportunity to develop relevant knowledge and practices. In a professional development (PD) program in this design-based research, 24 teachers were involved in adaptation of a learning environment supporting inquiry in the outdoors that included the use of mobile technologies. They first experienced the learning environment as learners, then adapted it for their own use, and finally, enacted the adapted environment with peers. We examined the scope and character of teacher involvement in adaptation, and the consequent professional growth, by analyzing observations, questionnaires, interviews and the adapted learningenvironments. Findings indicate that all teachers demonstrated change processes, including changes in knowledge and practice, but the coherence of the learning environments decreased when substantial adaptations were made. Some teachers demonstrated professional growth, as reflected by their implementation of ideas learned in the PD program in their daily practice, long after the PD program had ended. This study demonstrates how the Teachers as Designers approach can support teacher learning and illustrates productive use of scaffolds for teacher growth and professional development.
\end{abstract}

Keywords: Teachers as Designers (TaD), mobile learning, teacher professional development (PD), TPACK, outdoor inquiry

\section{Introduction}

Material published as part of this publication, either on-line or in print, is copyrighted by the Informing Science Institute. Permission to make digital or paper copy of part or all of these works for personal or classroom use is granted without fee provided that the copies are not made or distributed for profit or commercial advantage AND that copies 1) bear this notice in full and 2) give the full citation on the first page. It is permissible to abstract these works so long as credit is given. To copy in all other cases or to republish or to post on a server or to redistribute to lists requires specific permission and payment of a fee. Contact Publisher@InformingScience.org to request redistribution permission.

\section{Editor: Janice Whatley}

Teachers have always engaged in the design of curriculum materials as part of their profession (Laurillard, 2012). Indepth familiarity with their students allows teachers to create new activities or adapt existing ones to improve implementation of curriculum materials (Gerard, Spitulnik, \& Linn, 2010). This often creates a sense of ownership of the curriculum materials, supporting the implementation effort (Cviko, McKen-

An earlier, shorter version of this paper was presented at the Chais conference 2015, in Raanana, Israel, and included in Y. Eshet-Alkalai, I. Blau, A. Caspi, N. Geri, Y. Kalman, \& V. Silber-Varod (Eds.), Proceedings of the 10th Chais Conference for the Study of Innovation and Learning Technologies 2015: Learning in the Technological Era. Raanana: The Open University of Israel. 
ney, \& Voogt, 2014). The rapid developments in informational communication technologies in general, and online educational resources in particular, alongside the encouragement to integrate technology in their teaching and learning, motivate today's teachers to take part in the effort to design technology-enhanced learning (TEL) activities for their students.

Supporting inquiry learning, and especially outdoor inquiry learning, is particularly challenging for teachers. Inquiry teaching in the outdoors is an approach to improve student understanding of scientific principles related to the natural world and the nature of science (Osborne, 2014), while also increasing social and affective outcomes (Tal, Lavie Alon, \& Morag, 2014). However, supporting both inquiry and outdoor learning introduces significant pedagogical challenges for teachers. For instance, the unique type of guidance required for deepening the inquiry process (Crawford, 2000), especially when it is conducted in the field, as well as the need to teach in an unfamiliar environment (Tal, 2001). These often discourage teachers from outdoor teaching (Tal, 2001).

Teachers have a key role in supporting inquiry learning (Crawford, 2014). This role is even more significant when inquiry is conducted in the outdoors, in which the teacher must bridge between what students learn in the field and what they learn in class (Tal et al., 2014). However, despite the advantages of guiding their own students in the field, many teachers prefer to appoint external professional instructors to guide students in outdoor activities (Tal \& Argaman, 2005; Tal, Bamberger, \& Morag, 2005). In such a manner, a disconnect may form between the material taught in the classroom and that learned outdoors, and the teacher's advantage of familiarity with the students and their learning characteristics is lost. It seems that specifically in these complex learning environments the role of the teacher as a curriculum designer could be essential. Furthermore, teachers, much more than external guides, can design activities that streamline the learning between the different settings using mobile technologies (Kali, Sagy, Kuflik, Mogilevsky, \& Maayan-Fanar, 2015).

In this study, we have examined how teachers may be supported in teaching inquiry in the outdoors via a technology-enhanced learning environment. Using an approach of "teachers as designers of technology-enhanced learning" (TaD of TEL) (Kali, McKenney, \& Sagy, 2015), we sought to provide teachers with opportunities to develop their knowledge and expertise in outdoor inquiry teaching. During the professional development (PD) program, teachers used a TEL environment that was developed for the study, which includes a website and mobile applications for supporting outdoor inquiry. After experiencing the use of this learning environment for their own learning, the teachers learned how to adapt it to create a new learning environment tailored for their students. Finally, they implemented the adapted environment with their peers, who used the environment as learners. The study examined how the unique design of the PD program contributed to teachers' professional development and growth in the context of teaching inquiry in the outdoors. We examined the professional changes teachers went through during the PD program and afterwards, to address the following research questions:

1. In what ways was teachers' involvement in the PD program expressed in their design processes and products?

2. How were the teacher professional development and growth processes expressed following the program?

\section{Theoretical Background}

The theoretical grounding for this study integrates research that deals with (a) the Teachers as Designers of Technology-Enhanced Learning (TaD of TEL) approach, (b) outdoor inquiry learning and the challenges it presents for teachers, and (c) the potential of mobile learning incorporated within TEL environments to address such challenges. 


\section{Teachers as Designers of Technology-Enhanced Learning}

Literature dealing with the professional development of teachers indicates a number of properties that make PD programs successful (Loucks-Horsley, Love, Stiles, Mundry, \& Hewson, 2003; Penuel, Fishman, Yamaguchi, \& Gallagher, 2007):

- focusing on teachers' pedagogical skills and content knowledge,

- providing opportunities for active learning,

- making connections to classroom practices,

- modeling practice,

- encouraging collaboration between teachers,

- providing a coherent structure of the activities in the program.

One way to employ these properties is to involve teachers in designing or adapting curriculum materials. Studies have shown that alongside the professional development, which is expressed, for example, by adoption of new pedagogical approaches (Dori \& Herscovitz, 2005; Tal, Dori, \& Keiny, 2001), involvement in curriculum design can promote teachers' sense of ownership of the curriculum materials (Cviko et al., 2014) as well as improve their implementation (Davis \& Varma, 2008; Dori \& Herscovitz, 2005; Gerard et al., 2010; Shamir-Inbal, Dayan, \& Kali, 2009; Voogt et al., 2015; Voogt et al., 2011).

Involving teachers in the development of curriculum materials as a means for their professional development is not a new approach. However, the rapid advancements in technology in the past decade has brought more and more teachers to use, adapt, and design their own technologyenhanced materials in their teaching. As a result, the study of TaD of TEL has become a field of research. Challenges include better understanding of how to support teachers to participate in design endeavors, and revealing the factors that motivate them to do so (Kali, McKenney et al., 2015).

Studies from the last decade have characterized the type of knowledge required for teacherdesigners of TEL, entitled TPACK - Technological Pedagogical and Content Knowledge (Mishra $\&$ Koehler, 2006). These studies are based on and expand the insights of Shulman (1986), who argued that teachers' knowledge sources include both content knowledge (CK), related to the subject matter taught, and pedagogical knowledge (PK), related to teaching methods. Professional teaching, according to Shulman, involves rich understanding and knowledge sources of both types, as well as a unique type of knowledge that merges them - pedagogical content knowledge (PCK). This knowledge assists teachers in choosing pedagogical strategies that are specifically suited for teaching certain contents, in predicting the difficulties that students may encounter while learning these contents, and in finding ways to assist student to cope with such challenges. Mishra and Koehler (2006) have expanded this theory, adding a third knowledge source - technological knowledge (TK). This type of knowledge source is required for teachers who integrate technology within their teaching and includes acquaintance with diverse technological tools and skills for using them. When technological knowledge is merged with pedagogical-content knowledge, a new type of knowledge is formed - technological pedagogical and content knowledge (TPACK), which indicates a teacher's skill to make appropriate use of technology for supporting various combinations of pedagogical strategies, content, and context. Similar to PCK, which is a unique type of knowledge, a teacher who holds both technological knowledge and pedagogical-content knowledge will not necessarily know how to integrate the two.

Studies that have explored processes of teacher learning have shown that the involvement of teachers in the design or adaptation of technology-enhanced curriculum materials, when appropriately supported, can advance the development of TPACK (Koehler \& Mishra, 2005; Voogt et al., 2011). Support for this process may be embodied in learning environments in the form of 
scaffolds that assist teachers not only to better understand the contents but also to develop the ways of thinking and action in the field (Reiser \& Tabak, 2014). Svihla, Reeve, Sagy, and Kali (2015) characterize a "fingerprint pattern" of supports that can assist teachers to develop TEL design skills and knowledge. These include (a) modeling design practices, (b) encouraging dialogue between teachers while they develop their artifacts, and (c) providing opportunities for teachers to develop real world activities for students (rather than imagined scenarios). These can be reached by employing a "studio approach" in which teachers are guided during their design process and constantly provide and receive formative feedback (Crowther, 2013; Kali \& RonenFuhrmann, 2011).

In this study, we chose to focus on teachers who adapt a technology-enhanced learning environment for supporting outdoor inquiry. "Outdoor inquiry" is a pedagogical approach for encouraging students to engage in investigations that include data collection outside the classroom. It is sometimes referred to as field investigation (e.g., Tal \& Abramovitch, 2012) or field study (e.g., Wee, Shepardson, Fast, \& Harbor, 2007); however, it should be distinguished from the term "field study" in its methodological meaning. Outdoor inquiry is a mandatory requirement in the curricula for biology and environmental sciences in Israel. Nonetheless, as elaborated below, the implementation of this pedagogical approach introduces many challenges for teachers, which technology in general and mobile technology in particular (e.g., smartphones and tablets) may help to address.

\section{Challenges in Outdoor Inquiry Teaching}

Inquiry learning constitutes a key component in teaching science all over the world. The reason for this lies in the potential of the inquiry process for advancing students' understanding of scientific ideas and the ways they are developed (nature of science), as well as core ideas and concepts that cut across scientific disciplines (NRC, 2012; Osborne, 2014). To support achieving these goals, the NRC K-12 framework (NRC, 2012) suggested that students would participate in scientific practices that express the nature of scientific inquiry. These practices require both procedural and epistemic knowledge concerning the way in which scientific knowledge is constructed. For example, one of the most important practices in science is the ability to present an evidence-based theory. This aspect of scientific inquiry relies on the skill to compare and choose between alternative theories and may be expressed while engaging in evidence-based argumentation (Osborne, 2014). Scientific inquiry may occur in a range of settings - in the classroom, in the laboratory, or outside the school. Each of these settings entails advantages and disadvantages for learners, but when scientific principles that are related to the natural world are at hand, there is a major advantage for learning outside the classroom. Outdoor instruction has the potential to promote cognitive aspects of learning, due to the natural context in which the content is explored. Additionally outdoor instruction can promote social interactions that may empower learning and promote affective outcomes such as positive changes in students' attitudes towards the environment (Morag \& Tal, 2012; Tal et al., 2014).

Nonetheless, teachers who facilitate inquiry processes encounter many difficulties. Such challenges can stem from insufficient scientific knowledge or understanding of the nature of the inquiry process (Crawford, 2014; Zion, Cohen, \& Amir, 2007). Challenges can also arise when teachers are missing the pedagogical knowledge and experience required for facilitating inquiry. These include shifting between a range of roles or adapting curriculum materials for the specific needs of their students (Crawford, 2000, 2014). Failure in coping with these challenges can lead to superficial processes that fail to achieve the goals of inquiry to deepen students' scientific ideas and their understanding of the nature of science. The result is that often such teaching leads students to conduct experiments that are technically correct but does not encourage them to develop critical thinking (Osborne, 2014). 
Facilitating inquiry in the outdoors requires teachers to cope with these challenges in a setting with high unpredictability, leading teachers to feel insecure (Dillon et al., 2006; Tal, 2001). A review of the literature on field trips has shown that the pedagogy that teachers implement is crucial for the success of the field trip. Specifically, the ways by which teachers bridge classroom content with the outdoor environment is a critical factor (Lavie Alon \& Tal, 2015; Tal et al., 2014). Part of this bridging can be accomplished by designing preparation and summarizing activities for the field trip (Orion, 1993; Orion \& Hofstein, 1994). Unfortunately, the practical and theoretical knowledge that has accumulated in the past years regarding best practices in facilitating field trips is seldom implemented (Morag \& Tal, 2012). In this study, we decided to take advantage of what technology can offer to address some of the challenges inherent to outdoor inquiry teaching.

\section{The Use of Mobile Technologies for Outdoor Inquiry Learning}

With today's technology, scaffolds can be developed with a range of tools that can support learners to develop scientific practices as well as epistemic knowledge (Reiser \& Tabak, 2014). These tools, which include also mobile technologies, can be used for organizing information, constructing knowledge, and supporting collaboration processes (Kali \& Linn, 2007). The use of mobile technologies for learning - "mobile learning" - has been defined as a type of learning that combines interactions among people, the usage of technology, and the occurrence in a range of settings, including indoor and outdoor environments (Sharples, Taylor, \& Vavoula, 2007). By providing learners with just-in-time and just-in-place information required for their inquiry and by providing them with infrastructures for organizing collected data, mobile technology can support learning in various settings (Cahill et al., 2011; Land \& Zimmerman, 2015; Vavoula, Sharples, Rudman, Meek, \& Lonsdale, 2009). In addition, mobile technologies, when properly designed, can enable personalization of learning and student-oriented pedagogies (Anastopoulou et al., 2012; Looi et al., 2011). For example, Looi et al. (2011) showed that student-led inquiry with mobile technologies in field trips to zoos contributed to students' understanding of scientific ideas and improved their achievements; Land and Zimmerman (2015) showed how the integration of i-Pads in family visits to a botanic park advanced discourse between learners while exploring trees in their surroundings. Another important advantage of integrating mobile learning in outdoor inquiry programs is the potential of streamlining learning between the various learning settings, such as home, classroom, and field (Kali, Sagy et al., 2015).

In order to exploit the potential of technological tools to support educational processes, learning environments can be designed to embed appropriate pedagogical approaches (Salomon \& BenZvi, 2006). For instance, the major difference between web 1.0 and web 2.0 technologies is the shift from information consumption to a more participatory role of the user, which includes contribution of content and ideas to the web, as well as their negotiation with peers (Cormode \& Krishnamurthy, 2008). This technological shift corresponds to a shift in modern education, from a focus on individual knowledge acquisition to a more participatory and active view of the learning process (Kali, Tabak et al., 2015).

An important aspect of technology-enhanced learning environments in science is coherence (Fortus \& Krajcik, 2012; Kali, Linn, \& Roseman, 2008). Coherence refers to the linkage of ideas, the depth to which they are taught, and the continuity of contents within various parts of the curriculum. However, teachers who are experienced in inquiry teaching do not necessarily have the TPACK required for integrating the technology in a coherent manner. This applies all the more so for teachers who lack appropriate knowledge and experience in guiding inquiry. Therefore, to enable science teachers to take advantage of technology for outdoor inquiry teaching, it is not sufficient to provide them with the technological tools. Science teachers should be provided with the opportunity and appropriate guidance to develop the knowledge and the skills required in or- 
der to design technology-enhanced activities that can assist them to guide students in inquiry learning in the outdoor environment.

As part of the current study, we have developed a teacher PD program that involves teachers in the design of a TEL environment for supporting outdoor inquiry. In view of the recommendations of the research dealing with TaD of TEL environments, the PD program was designed to enable teachers to a) experience technology-supported outdoor inquiry as learners, b) adapt the learning environment for their own potential use, and c) practice the role of mentoring outdoor inquiry using the adapted learning environment. To track teachers' professional development and growth processes, we used Clarke and Hollingsworth's (2002) Interconnected Model of Professional Growth. This model allows for examination of the individual processes that teachers undergo as part of their professional development as well as the identification of long term professional growth processes.

\section{Methodology}

The current study is a first iteration in a design-based research (DBR). This methodological approach involves multiple cycles of design-enactment-analysis, which lead to refinement of the design as well as to advancement of theoretical aspects of the learning afforded by the designed environment (Barab \& Squire, 2004). We chose to combine quantitative and qualitative research methods according to the "mixed method" approach, as is often conducted in DBR. In this approach, each of the research methods unfolds a different aspect of the topic explored, allowing revelation of a wider picture of the phenomenon (Ercikan \& Roth, 2006; Johnson \& Onwuegbuzie, 2009).

We used Sandoval's (2014) technique for mapping conjectures in DBR, which enabled us to articulate high level conjectures from which we have started the study and stem from our synthesis of the research literature. These conjectures were embodied into our design of the learning environment that we used for the PD program and served as the basis for our design conjectures. Design conjectures describe the way we envisioned that processes, which Sandoval entitles "intermediate processes", will take place as a result of teachers' interaction within the designed learning environment. Finally, we articulated theoretical conjectures regarding how the intermediate processes will lead to the intervention outcomes that we anticipated and sought to further explore through this study.

The mapping of the conjectures for the current study is depicted in Figure 1. Based on the theoretical background described above, we assumed that the professional growth of teachers as implementers of outdoor inquiry would involve their experience in learning, adaptation, and mentoring activities that streamline learning between the field, classroom, and home. We assumed that such professional growth would develop through teachers' participation in activities that:

a) use technology for streamlining learning across the different learning settings - home, classroom, and outdoors (Kali, Sagy et al., 2015),

b) support their shifting between diverse roles as learners, curriculum adaptors and mentors of outdoor inquiry (Svihla et al., 2015), and

c) utilize a design studio approach (Crowther, 2013).

Our design conjectures were that active participation in the PD program would lead to change processes in teachers, as expressed in Clarke and Hollingsworth's (2002) professional growth model: in the personal domain (individual knowledge, beliefs and attitudes), in the domain of practice (teaching in class or any other practical experience), and in the domain of consequence (salient outcomes that result from pedagogical experimenting). Our theoretical conjecture was that these mediating change processes would lead to professional growth that would be expressed in continued professional development of teachers and continued changes in the long term, in- 
cluding changes in practice. In other words, as expressed in the conjecture map (Figure 1), we assumed that following the PD program, teachers would continue to implement outdoor inquiry using technology. Ultimately, we seek that teachers will design activities for preparing and summarizing the field activity, streamline learning between settings, and provide scaffolds that will help students conduct more in depth, critical inquiry.

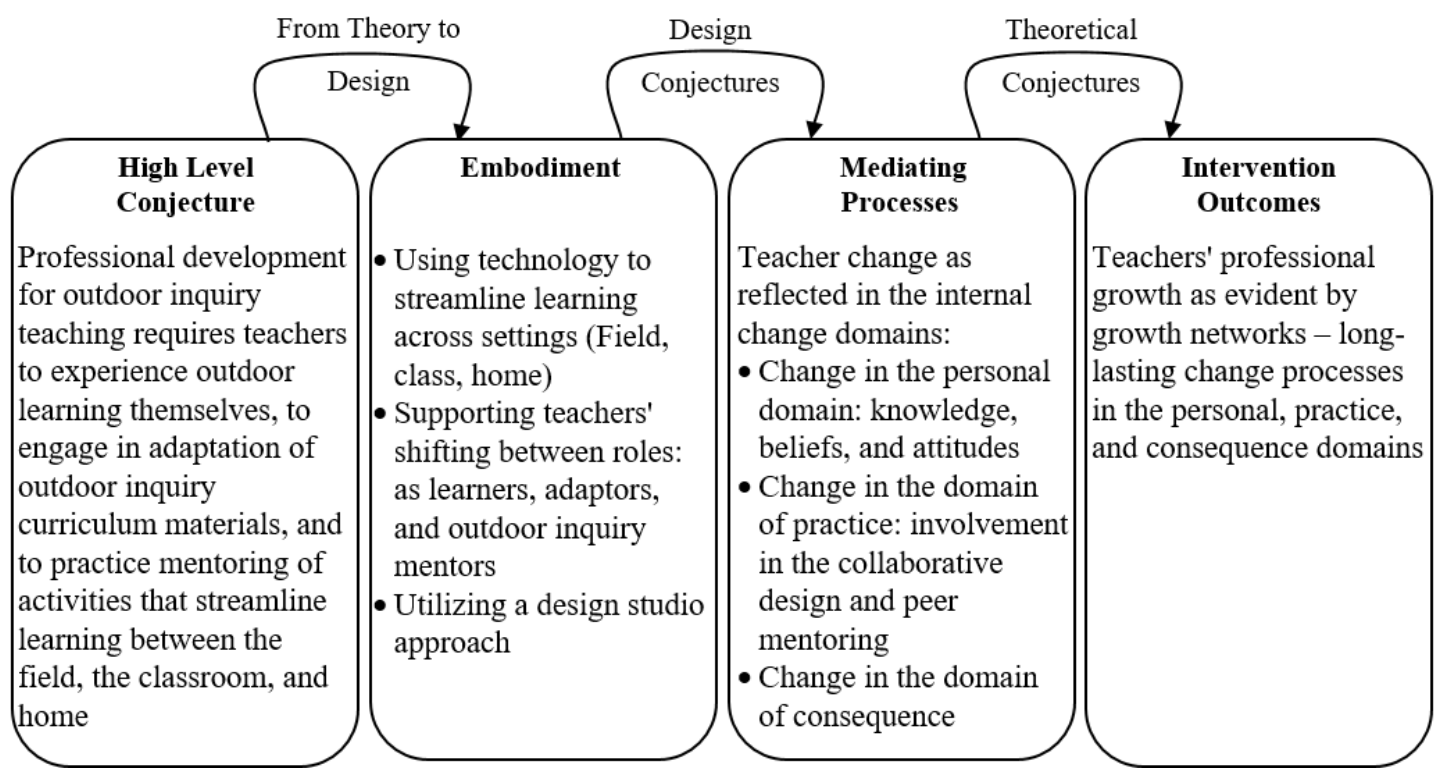

Figure 1: Conjecture mapping of the current study. Adapted from Sandoval (2014)

\section{Context and Design}

The teacher PD program included three face-to-face meetings and one online meeting (with a total of 14 hours), which were conducted over a period of nine weeks, facilitated by the authors of this paper. We developed an interactive website (using Google Sites) which included all the instructions for the activities and collaborative spaces for teachers' work (Figure 2). The website was adjusted for use by mobile phones in the field. The activities were designed with the aim of supporting teachers as designers of TEL. For this purpose, activities were designed around the three roles that teachers played in the PD program - learners, adaptors, and mentors - and for supporting learning using the studio approach (Crowther, 2013) in a range of social structures individual, small group, and the entire group (Bielaczyc, 2006). For each of the teacher roles we developed a number of pages in the website. In addition, scaffolds were integrated to support teachers" design process using the "fingerprint pattern" of supports (Svihla et al., 2015). Throughout the PD program plenary discussions were integrated, dealing with the PD content as well as with reflection on the learning processes.

In the first stage, "teachers as learners", teachers had an opportunity to use a section of the website designed to support them as learners of the contents - ecological processes that they explored in an ecological garden. This included a set of inquiry activities that were organized in three parts - a preparation activity, an outdoor activity in the ecological garden, and a summary activity (Orion, 1993). The outdoor activity was supported with an "outdoor learning module" (see Figure 2) of the website that teachers accessed using their smartphones. 


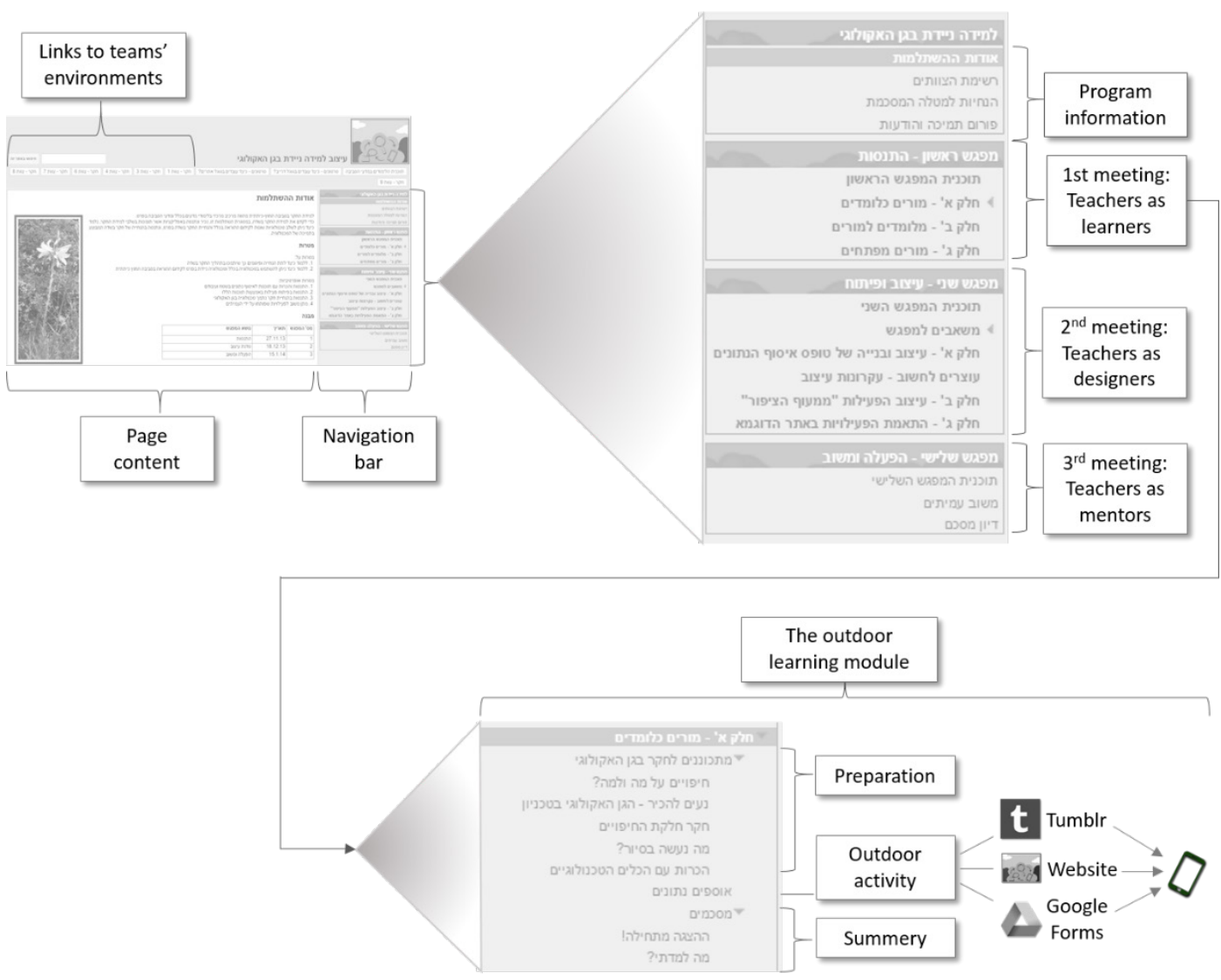

Figure 2: Description of the components of the PD-program learning environment

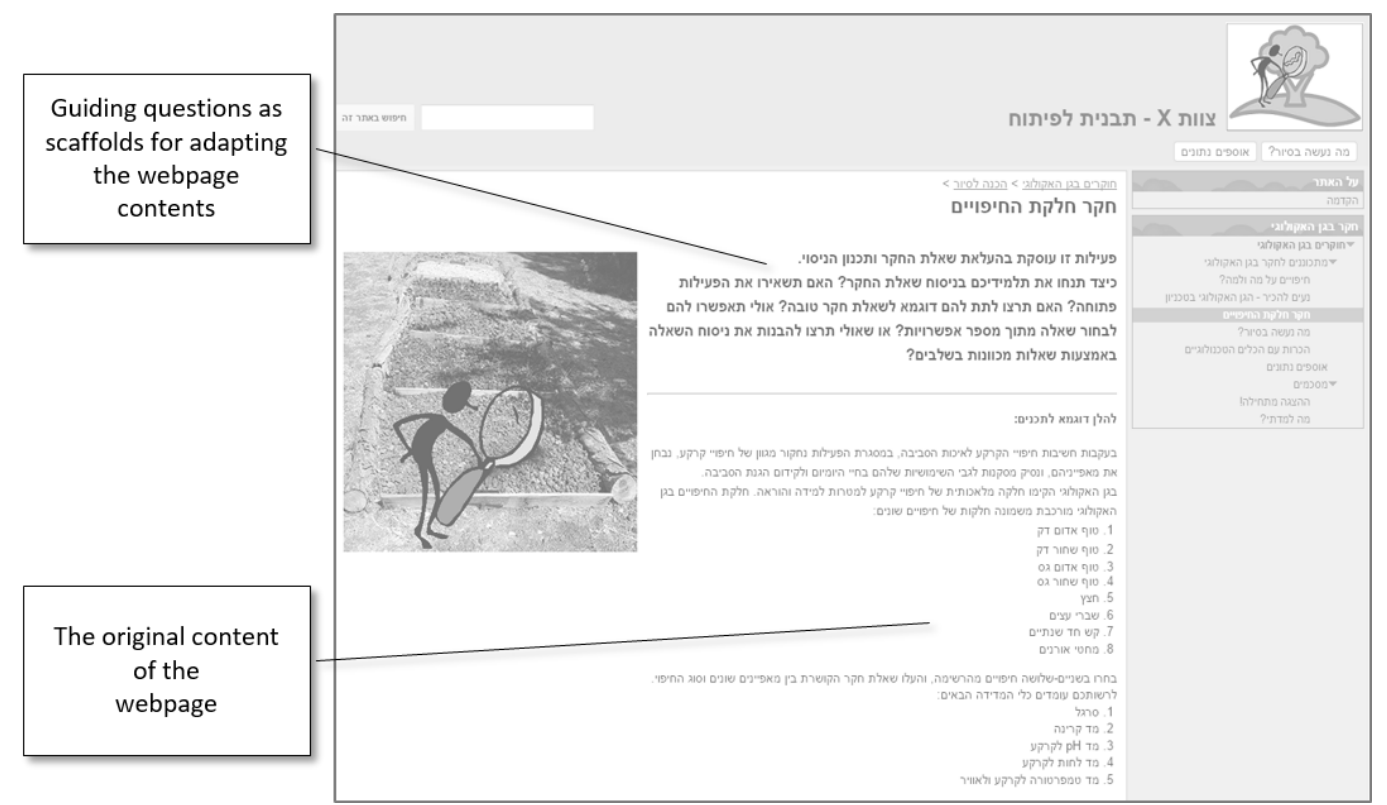

Figure 3: Components of a webpage for teachers' editing

To support the inquiry process, the activity was divided into stages (sub-pages in the website). Each of the stages included activities that guided a specific inquiry process, constructed according 
to design principles for inquiry learning (Kali, 2008; Kali \& Linn, 2007) and in a manner that would promote critical thinking and advance scientific practices (Osborne, 2014). For example, the "investigating different types of mulch" page of the website, shown in Figure 3, shows an activity that included a description of the types of mulch with which measurements were designed to take place as part of the inquiry process. This page also included guiding questions to provide teachers with scaffolds for their formulation of an inquiry question: "What is your inquiry question? Why is it important to study the question that you have asked? What factors would you like to study in order to answer this inquiry question? How is it possible to measure these factors? What will you be able to learn from the findings? How would it be possible to implement the conclusions for advancing environmental protection?" In addition, the outdoor learning module included online forms to help teachers collect data in the ecological garden using their smartphones. We used Tumblr, a social networking platform, for taking photos and automatically incorporating them within teachers' workspaces on the website. These applications were chosen following a pilot study that examined their usability, and have been shown to enable the streamlining of learning between settings that we sought to support (Levy, Tal, \& Kali, 2013).

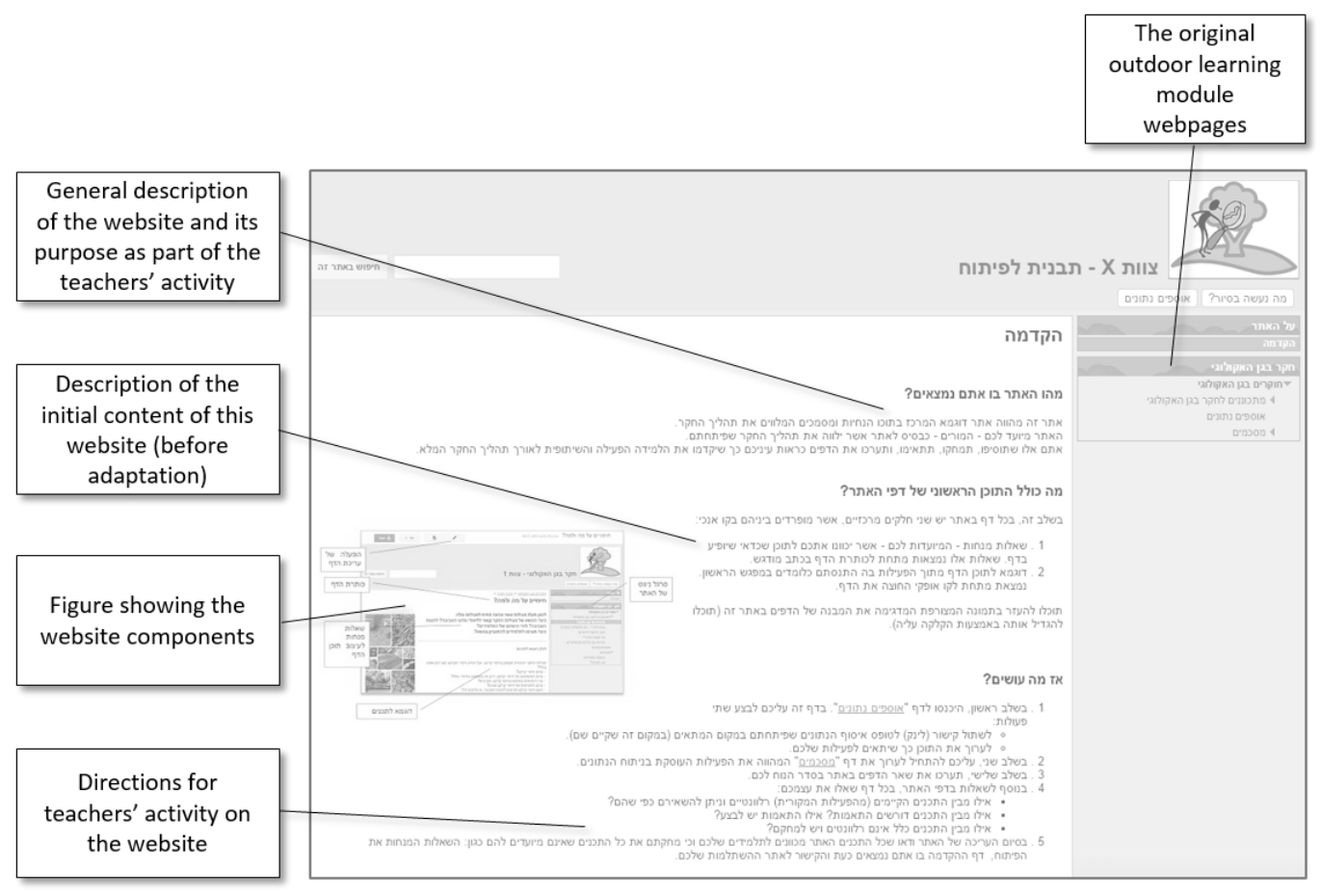

Figure 4: The introduction webpage of a team learning environment

In the second stage, "Tad of TEL", teachers worked in collaborative teams to design their own learning environments. The meetings were conducted in a design studio format (Crowther, 2013), with us (the authors) as facilitators. Each team of teachers was provided with a copy of the outdoor learning module from the PD learning environment and a set of scaffolding activities for adapting this module for their own use and for developing appropriate preparation and summarizing activities (Figure 4). For example, on the "investigating different types of mulch" webpage shown in Figure 3, in addition to the activity of the original outdoor learning module at the bottom of the page, the top of the page was intended for teachers' role as designers. Thus, it included the purpose and rationale for the design of the original activity, as well as scaffolds for the adaptation process: "This activity deals with asking the inquiry question and planning the experiment or observation. How would you guide your students to draft the inquiry question? Would you leave the activity open-ended? Would you want to give the students an example of a good inquiry 
question? Perhaps you would want to enable your students to choose a question out of a number of options? Or maybe you would like to assist students with guiding questions that would help them articulate their inquiry question?" Teachers in each team adapted their module according to the inquiry topic they chose to teach. For further support in the design process, the teachers were exposed to four design principles for designing their learning environment and were guided to work in collaborative documents within the website to summarize the ideas that were raised during the design process. During the online meeting, teachers received assistance and technical guidance for using Google Apps' tools for editing their learning environments (the guidance was conducted using JoinMe - a platform that enables screen-sharing in synchronous online meetings).

The PD program, if analyzed in terms of TPACK (Mishra \& Koehler, 2006), dealt with the application of three types of knowledge - content, pedagogy, and technology - and with each of their integrated combinations. At the first stage, the teachers were engaged in conceptual development of goals with respect to the content they wanted to teach (content-pedagogy). Then, teachers were exposed to some design principles for inquiry activities in the outdoor environment (pedagogy). Afterwards, they engaged in planning the activities for their students to participate in (contentpedagogy). Finally, teachers learned how to use Google Apps to make the adaptations in the technological learning environment (technology) to support the content goals and the pedagogical characteristics of the activities (content - pedagogy - technology).

The third, and last stage of the program, "teachers as mentors", involved teachers in peer mentoring of inquiry in the outdoors using the teams' adapted learning environments. Teachers gave and received feedback from their peers regarding the activities they developed (embedded in the learning environments) and the mentoring that they provided (in the outdoors).

Following the PD meetings, teachers were provided with additional feedback concerning their adapted learning environments from one of the PD mentors and were requested to (a) refine their learning environments according to the feedback and (b) analyze the activities that they created according to the design principles that they learned.

\section{Participants}

In this study, 25 teachers who had participated in a PD program for leading environmental science teachers took part. All of them had at least nine years of experience in teaching, including teaching of inquiry in the outdoors. During the PD program activities, the teachers worked in seven teams of three to four members. (Please note that all the names used in this paper are pseudonyms.)

\section{Data Collection and Analysis}

Data was collected from:

- observations that were conducted during the PD meetings for examining the participation of teachers in the design of the learning environment,

- analyses of the teachers' activity in editing their team's adapted learning environments,

- open-ended questionnaires that were conveyed before and after the PD program, and

- semi-structured interviews that were conducted after the end of the PD program. 
The way we used these sources to answer the research questions is summarized in Table 1.

Table 1: A summary of the data sources and how they were used to answer the research questions

\begin{tabular}{|c|c|c|c|}
\hline $\begin{array}{l}\text { Research } \\
\text { question }\end{array}$ & Data source & Purpose & Data analysis \\
\hline \multirow{3}{*}{$\begin{array}{l}\text { 1. In what ways was } \\
\text { teachers' in- } \\
\text { volvement in the } \\
\text { PD program ex- } \\
\text { pressed in their } \\
\text { design processes } \\
\text { and products? }\end{array}$} & $\begin{array}{l}\text { Observations - taking field } \\
\text { notes and summarizing } \\
\text { insights from the program } \\
\text { meetings }\end{array}$ & $\begin{array}{l}\text { Examining the participa- } \\
\text { tion of teachers in the } \\
\text { design of the learning } \\
\text { environment }\end{array}$ & $\begin{array}{l}\text { Qualitative evaluation } \\
\text { of teachers participa- } \\
\text { tion in the program } \\
\text { activities }\end{array}$ \\
\hline & $\begin{array}{l}\text { Automatic documentation } \\
\text { of teacher activity (num- } \\
\text { ber and content of edits) } \\
\text { in the team's adapted } \\
\text { learning environments }\end{array}$ & $\begin{array}{l}\text { Examining the way } \\
\text { teachers participated in } \\
\text { the development of the } \\
\text { team's adapted learning } \\
\text { environments }\end{array}$ & $\begin{array}{l}\text { Quantitative analysis - } \\
\text { counting the number of } \\
\text { editing events using } \\
\text { Google's 'recent site } \\
\text { activity' }\end{array}$ \\
\hline & & & $\begin{array}{l}\text { Qualitative analysis to } \\
\text { evaluate the level of } \\
\text { adaptation and the co- } \\
\text { herence of the adapted } \\
\text { learning environments }\end{array}$ \\
\hline \multirow{4}{*}{$\begin{array}{l}\text { 2. How were the } \\
\text { teacher profes- } \\
\text { sional develop- } \\
\text { ment and growth } \\
\text { processes ex- } \\
\text { pressed following } \\
\text { the program? }\end{array}$} & $\begin{array}{l}\text { Open-ended question- } \\
\text { naires (views regarding } \\
\text { technology integration) - } \\
\text { before and after the PD } \\
\text { program }\end{array}$ & $\begin{array}{l}\text { Comparison of teacher } \\
\text { views regarding the inte- } \\
\text { gration of technology in } \\
\text { their teaching before and } \\
\text { after the PD program }\end{array}$ & \multirow{2}{*}{$\begin{array}{l}\text { Qualitative analysis to } \\
\text { identify emergent } \\
\text { themes and quantita- } \\
\text { tive analysis to evalu- } \\
\text { ate the frequencies of } \\
\text { the themes }\end{array}$} \\
\hline & $\begin{array}{l}\text { Open-ended question- } \\
\text { naires (views regarding } \\
\text { PD program) - after the } \\
\text { PD program has ended }\end{array}$ & $\begin{array}{l}\text { Examination of teacher } \\
\text { views towards the PD } \\
\text { program }\end{array}$ & \\
\hline & $\begin{array}{l}\text { Semi-structured inter- } \\
\text { views - one to two } \\
\text { months after the PD pro- } \\
\text { gram has ended }\end{array}$ & $\begin{array}{l}\text { Revealing teachers' } \\
\text { views about the PD pro- } \\
\text { gram and what they } \\
\text { thought about future inte- } \\
\text { gration of technology in } \\
\text { their teaching }\end{array}$ & \multirow{2}{*}{$\begin{array}{l}\text { Qualitative analysis of } \\
\text { teachers' answers us- } \\
\text { ing Clarke and Hol- } \\
\text { lingsworth's Intercon- } \\
\text { nected Model of Pro- } \\
\text { fessional growth (2002) }\end{array}$} \\
\hline & $\begin{array}{l}\text { Semi-structured inter- } \\
\text { views -six to nine months } \\
\text { after the PD program has } \\
\text { ended }\end{array}$ & $\begin{array}{l}\text { Revealing long term ef- } \\
\text { fects of the PD program }\end{array}$ & \\
\hline
\end{tabular}

\section{Analysis of teachers' activity in editing their team's learning environment}

As stated previously, each team received a copy of the outdoor-inquiry learning module. Each team adapted the module in accordance with the inquiry topic teachers chose to develop. We analyzed each of the seven adapted learning environments in a quantitative and qualitative manner, as we explain below. The purpose of these analyses was to assess the way teachers participated in adapting the learning environments.

The quantitative assessment was conducted for the editing events of the teachers in the teams' adapted learning environments as documented in the "recent site activity" on Google sites. The automatic documentation includes both minor editing actions (such as language editing) as well as significant editing activities (such as changing and adding contents, links, images, and questions). For each teacher, editing events of both types were analyzed. Because this assessment is 
not sufficient and cannot provide comparable results, we carried out a qualitative assessment of the adaptations using a rubric we developed. The rubric enabled us to assess the essence of the adaptations in comparison to the original outdoor learning module that teachers adapted, and to scrutinize the coherence of the adapted learning environment. This rating was made for the three parts of the adapted learning environment according to the three-stage model for integrating field trips (Orion, 1993) in the curriculum: (a) the preparation activity, (b) the outdoor activity in the ecological garden, and (c) the summary activity. This was carried out in two steps that are detailed below.

Firstly, the score of the adaptation was rated on a 0-3 scale according to the rubric (Table 2). Each of the three parts of the adapted learning environment was scored on this scale. The total (maximum of 9, with 3 points for each part) specified the level of the adaptation: low $-0-3$, medium - 4-6, and high - 7-9.

\section{Table 2: Rubric for assessing the adaptation in the three parts of the outdoor learning module}

\begin{tabular}{|c|c|c|}
\hline $\begin{array}{l}\text { Adaptation score (for } \\
\text { each of the } 3 \text { parts of } \\
\text { the module)* }\end{array}$ & Description & Example adaptations made by teachers \\
\hline 3 & $\begin{array}{l}\text { Addition of an activity with } \\
\text { a new pedagogical ap- } \\
\text { proach that did not exist } \\
\text { in the original outdoor } \\
\text { learning module or re- } \\
\text { moval of a complete ac- } \\
\text { tivity, compared to the } \\
\text { module }\end{array}$ & $\begin{array}{l}\text { Activity added by the teachers for eliciting their } \\
\text { students' ideas (including misconceptions), as part } \\
\text { of the preparation for the inquiry. This activity did } \\
\text { not exist in the original module: } \\
\text { "For each of the statements below, please } \\
\text { indicate your degree of agreement between } \\
1 \text { to } 5 \text { regarding the ecological system and } \\
\text { the human intervention in the forest". }\end{array}$ \\
\hline 2 & $\begin{array}{l}\text { Addition to an existing } \\
\text { activity or change of an } \\
\text { existing activity in the } \\
\text { module without a change } \\
\text { in the pedagogical ap- } \\
\text { proach }\end{array}$ & $\begin{array}{l}\text { Scaffolds added to the guidelines for student data } \\
\text { processing and representation process: } \\
\text { "Create a graph that describes the relation- } \\
\text { ship between the distance from the pine tree } \\
\text { and the density of plants" } \\
\text { instead of a general guideline that appeared in } \\
\text { the module: } \\
\text { "Edit and process the data, find averages for } \\
\text { repeated measurements, and plot graphs } \\
\text { that describe your results". }\end{array}$ \\
\hline 1 & $\begin{array}{l}\text { Minimal adaptation of the } \\
\text { new content: minor } \\
\text { changes that are not sub- } \\
\text { stantial for the activity } \\
\text { structure }\end{array}$ & $\begin{array}{l}\text { Change of a title according to the new inquiry top- } \\
\text { ic: "Spice bed inquiry" instead of "investigating } \\
\text { different types of mulch". }\end{array}$ \\
\hline No adaptation (0) & No change & \\
\hline \multicolumn{3}{|c|}{$\begin{array}{l}{ }^{*} \text { The level of adaptation for the whole module was calculated as the sum of the scores for each of the } \\
\text { three parts (preparation activity, outdoor activity, summary activity) with a maximum score of } 9 \text { ( } 3 \text { points } X \\
\text { each part) }\end{array}$} \\
\hline \multicolumn{3}{|c|}{$\begin{array}{l}\text { Secondly, the intra-unit coherence, as described by Fortus \& Krajcik (2012), was examined in } \\
\text { each of the adapted learning environments. The coherence was assessed in two ways (Table } 3 \text { ): } \\
\text { (a) internal coherence for each of the three parts of the environment (only environments with ad- } \\
\text { aptations at a minimum score of } 2 \text { were included) with a maximum score of } 9 \text {, and (b) coherence } \\
\text { of the complete learning environment (for environments that included adaptations at a medium or } \\
\text { high level) with a maximum score of } 3 \text {. }\end{array}$} \\
\hline
\end{tabular}


Table 3: Rubric for assessing coherence of adapted learning environments

\begin{tabular}{|c|c|}
\hline Assessment criteria & Description \\
\hline $\begin{array}{l}\text { Internal coherence for each } \\
\text { part of the learning envi- } \\
\text { ronment }\end{array}$ & $\begin{array}{l}\text { Completeness and continuity of each part with regard to: } \\
\text { - Choosing appropriate technology to support the pedagogy } \\
\text { - Clarity of the instructions } \\
\text { - Relationship between title and content } \\
\text { - Continuity between activities }\end{array}$ \\
\hline $\begin{array}{l}\text { Coherence of the learning } \\
\text { environment as a whole }\end{array}$ & $\begin{array}{l}\text { Examination of the continuity of the activities within the learning environment } \\
\text { level with regards to: } \\
\text { - Uniformity of the terminology throughout the learning environment } \\
\text { - The relationship and the streamlining of knowledge between the ac- } \\
\text { tivities in the different inquiry stages }\end{array}$ \\
\hline
\end{tabular}

\section{Questionnaires}

The questionnaires included open-ended questions related to:

a) the way in which teachers incorporate technology (before the PD program)

b) important ideas teachers claimed to have learned in the program (after the PD program)

c) features in the program that they feel that have contributed to their learning (after the PD program)

d) teachers' willingness to integrate mobile technology in their teaching and the reasons for this (before and after the PD program)

Overall, 21 of the teachers responded to the questionnaire at the beginning of the PD program and 19 responded at the end of the program. Teachers' answers were analyzed according to Chi's (1997) "quantifying qualitative analyses of verbal data" approach. By coding the verbal data and seeking patterns, this approach allows for a quantitative analysis of the subjective themes that emerge from the qualitative analysis. According to this approach, we chose to analyze all the answers to the questionnaires. Each answer constituted one unit of analysis. First, categories that emerged inductively from the answers were defined. Then, similar criteria were merged and another analysis cycle was conducted according to this encoding. Afterwards, two more researchers conducted the analysis according to the encoding to establish inter-rater reliability. Each disagreement in the analysis was discussed until reaching an agreement of at least $95 \%$ among the researchers on the coded items. Finally, a summary of the number of statements was made for each criterion.

\section{Interviews}

Two rounds of semi-structured interviews were conducted. In the first round, nine of the teachers were interviewed, one to two months after the PD program has ended. These interviews lasted for about 45 minutes on average. Teachers were chosen for the interviews to represent two profiles that emerged from the data: (1) involved, motivated teachers who expressed satisfaction with the PD program, and (2) teachers who were not involved in the development or did not feel that they got much benefit from the PD program. During the interviews, the teachers were asked:

- what new things they had learned from the PD program

- how they thought the technology could be integrated for advancing outdoor inquiry teaching

- whether and how the way in which they would integrate the technology in their future teaching would change 
In the second round of interviews, seven teachers participated - six out of those who were interviewed in the first round and one additional teacher. The interviews were conducted six to nine months after the PD program has ended. The teachers who were interviewed in the second round were those who expressed (in the post questionnaire or in the first interviews) willingness to continue to integrate the technology in their teaching. In this interview, the teachers were asked whether and how they incorporated the technology in their teaching following the PD program.

The interviews transcripts and the teachers' answers to the questionnaires were analyzed according to the Interconnected Model of Professional Growth (Clarke \& Hollingsworth, 2002). The model differentiates between four domains in the teacher environment in which change may occur: one is an external domain - an external source of information or stimulus (such as teacher PD program) - and three are internal domains:

a) the personal domain - knowledge, attitudes and beliefs

b) the domain of practice - all forms of professional experimentation (such as an experimentation with a new teaching strategy)

c) the domain of consequence - salient outcomes (as perceived by the teacher) following professional experimentation

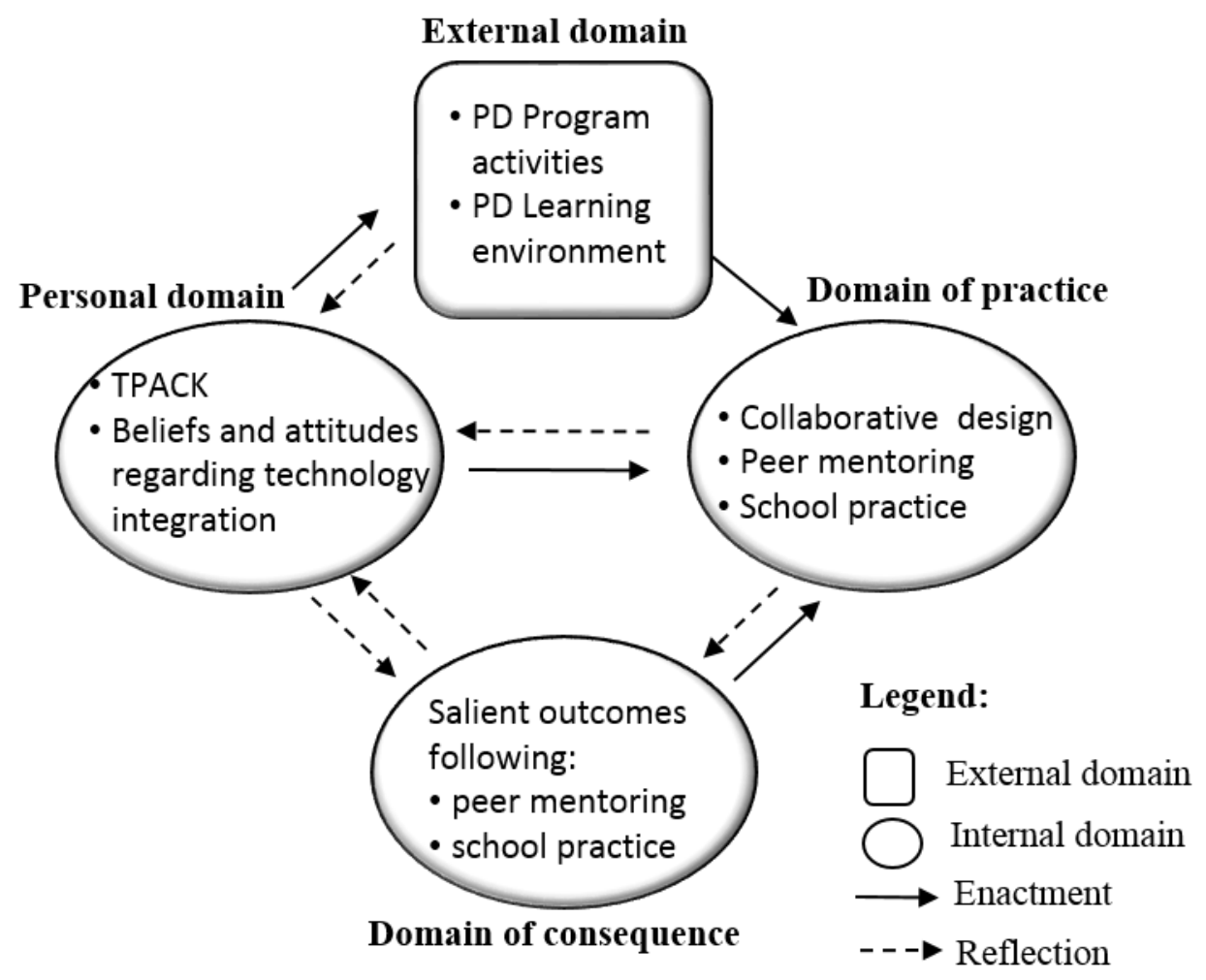

Figure 5: The Interconnected Model of Professional Growth as used in the data analysis. Adapted from Clarke \& Hollingsworth (2002)

The change processes of the teacher includes "change sequences". Each change sequence consists of changes that have occurred in at least two domains and one "mediation process", which includes "enactment" or "reflection" on the change. Long-lasting change sequences constitute "growth networks" and reflect a process of professional growth. We identified the changes that the teachers went through in the internal change domains and characterized the change sequences 
by indicating the mediating processes which led to the changes. The model and the way we used it within the current analysis are illustrated in Figure 5.

\section{Findings}

\section{Teachers' Involvement in the Design as Part of the PD Program}

The observations indicate that all the teachers participated in the design activities during the PD meetings. These activities, which we interpreted as belonging to the domain of practice (professional experimentation) included:

a) conceptual design of the intended activities for the learning environment (such as articulating the activity outline features: goals and a general description of the activity)

b) adaptations to the online learning environments including the development (from scratch) of online forms for learner data collection in the ecological garden

In addition, the analysis and the rating of the adapted learning environments using the rubric described above (Table 2) enabled us to identify differences in the level of adaptation between the different teams:

- in one learning environment (team A) adaptation that was scored as 2 was made only in one part (the outdoor activity) and therefore the whole adapted learning environment was rated at a low level (2 out of 9)

- in two learning environments the adaptations of the three parts summed up as 6 , and therefore, were rated at a medium level (6 out of 9)

- in four learning environments, the adaptations of the three parts summed up between 7 to 9, and were rated at a high level (between 7 to 9 out of 9)

Unlike the adaptations that were documented in the adapted learning environments of the teams, which constitute a product of an entire team, the documentation of the editing events of these environments describes the personal scope of work of each teacher. An analysis of the editing events of the 24 teachers reveals that the degree of teacher involvement in conducting the adaptations greatly varied:

- high involvement $-29 \%$ of the teachers (more than 20 editing events)

- medium involvement - 8\% of the teachers (6-19 editing events)

- low involvement $-17 \%$ of teachers (1-5 editing events)

- no involvement at all $-46 \%$ of the teachers

In addition, unsurprisingly, the level of the adaptation of the adapted learning environments was congruent with the number of personal editing events. Teachers whose number of editing events was high (within their team learning environment) demonstrated a high or medium level of adaptation (six environments out of seven). In other words, these environments included new pedagogical approaches that did not exist in the original activities of the outdoor learning module or changes of existing activities. Accordingly, in environments in which the volume of editing events of teachers was low, the level of adaptation of the environment was low.

The rating of the internal coherence of each part of the adapted learning environments showed that in all of them there was some impairment of coherence: five environments were rated, using the rubric for assessing coherence (Table 3), between 1 to 5 (out of 9), and two environments were rated as 7 and 8 . An analysis of the causes for the decreased internal coherence (Figure 6) showed that in all environments there were insufficient technical instructions for learners regarding how they should carry out the activities (e.g., lack of instructions for filling in the data collection form). Four of the environments displayed a mismatch between technology and pedagogy 
(e.g., there were no collaborative documents for student work even though students were expected to work collaboratively). Problems in the internal sequence arose when the order of activities did not make sense or when activities included instructions that were not in line with the place they were supposed be conducted (e.g., directions for conducting observations in the field as part of the summary activity that is supposed to take place at home / in school). Contradictions in contents stemmed from a difference between the questions appearing on the website and those appearing in the work documents.

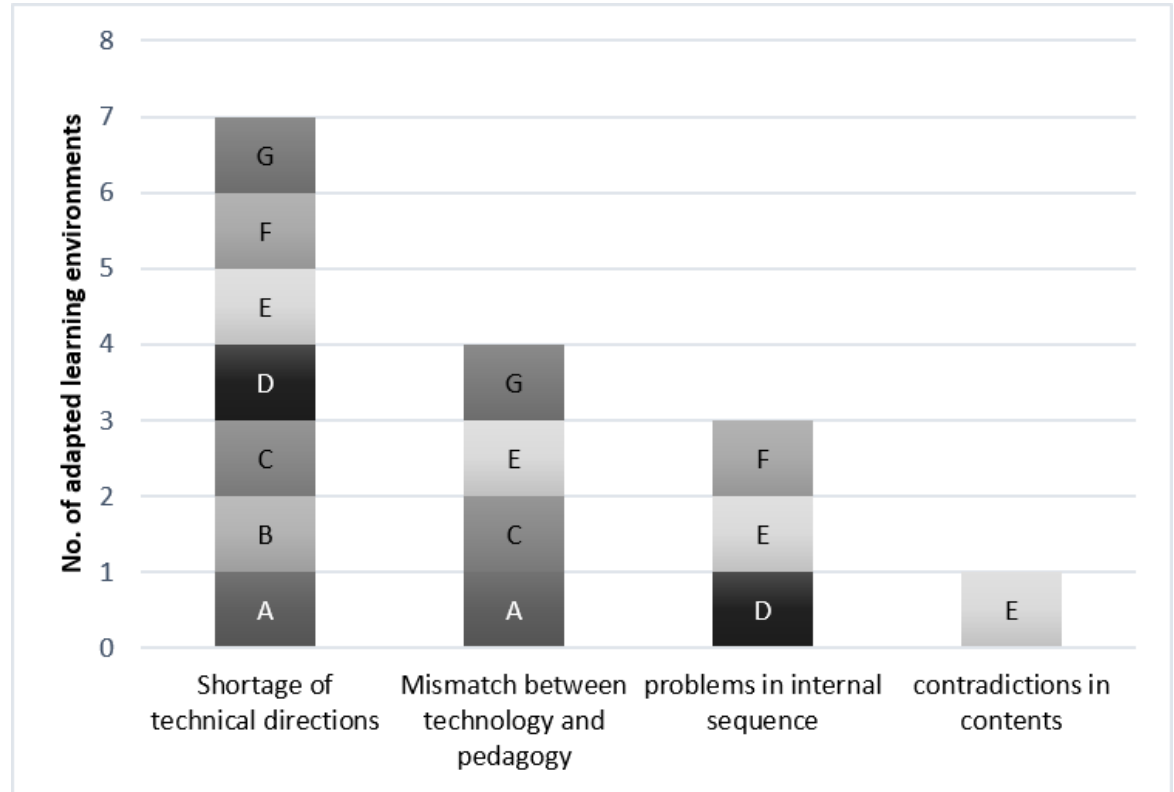

Figure 6: Causes for the decrease in internal coherence of the three parts of the learning environment.

The letters represent the seven adapted learning environments

Six of the seven adapted learning environments were examined according to the "coherence of the learning environment as a whole" criterion (in the environment of team A, only one of the three parts was adapted, therefore this environment was not examined according to this criterion). This examination showed that in five out of the six environments, adaptations decreased the coherence of the environment:

- in one environment (F) the coherence was maintained (rated at 3 out of 3 );

- in another environment (B) the coherence was rated at a medium level (2) due to lack of consistency in terminology;

- in the four remaining environments the coherence was rated at a low level (1) due to poor sequencing of activities, such as a wrong order or a cluster of unconnected activities. For example, in team E's learning environment, an activity guiding the students on how to work while being in the field was incorporated in the middle of the preparation part (designed to be conducted at home).

\section{Teachers' Professional Growth Following the PD Program}

\section{The change processes that teachers underwent}

As detailed below, all of the findings reveal that the teachers went through change processes at different levels according to Clarke and Hollingsworth's model (2002). Some went through 
changes in three domains - personal, practice, and consequence - and some in only two domains - personal and practice. To examine the change processes, we analyzed the questionnaires and the interviews with the aim of identifying the knowledge bases (included in TPACK) that the teachers use, their beliefs and attitudes toward the integration of technology in teaching, and the characteristics of their practice before and after the PD program.

A range of evidences of changes that teachers went through in the PD process was found in the first round of interviews ( 9 teachers). These were classified into the three change domains: the personal domain (knowledge, beliefs, and attitudes), the domain of practice (as professional experimentations during and after the PD program), and the domain of consequence. As can be seen in Table 4, all of the teachers went through change processes during the PD program in at least two of the three domains shown in Clarke and Hollingsworth's model (2002) - in the personal and in the practice domains. Three of the teachers reported changes in the domain of consequence as well. The following sections show the findings on which Table 4 is based upon.

Table 4: Types of internal change processes teachers went through

\begin{tabular}{|c|c|c|c|c|c|c|c|c|}
\hline \multirow{3}{*}{ Pseudonym } & \multicolumn{4}{|c|}{ Changes in the personal domain } & \multicolumn{3}{|c|}{ Changes in the domain of practice } & \multirow{3}{*}{$\begin{array}{l}\text { Changes in } \\
\text { the domain of } \\
\text { consequence }\end{array}$} \\
\hline & \multicolumn{3}{|c|}{ Knowledge* $^{*}$} & \multirow{2}{*}{$\begin{array}{l}\text { Beliefs and } \\
\text { attitudes }\end{array}$} & \multirow{2}{*}{$\begin{array}{c}\text { During the } \\
\text { program }\end{array}$} & \multirow{2}{*}{ In planning } & \multirow{2}{*}{ At school } & \\
\hline & TK & TPK & TPACK & & & & & \\
\hline Sama & 2 & 4 & 1 & 6 & 5 & 1 & 17 & 8 \\
\hline Adi & 2 & 12 & 1 & 4 & 3 & 0 & 6 & 5 \\
\hline Nura & 2 & 12 & 1 & 11 & 1 & 2 & 2 & 9 \\
\hline Avivit & 2 & 8 & 1 & 1 & 2 & 2 & 1 & 0 \\
\hline Malka & 2 & 6 & 1 & 5 & 4 & 2 & 1 & 0 \\
\hline Nihal & 4 & 6 & 0 & 8 & 4 & 2 & 0 & 0 \\
\hline Alon & 2 & 16 & 1 & 5 & 2 & 2 & 0 & 0 \\
\hline Michael & 4 & 18 & 0 & 2 & 1 & 0 & 0 & 0 \\
\hline Madi & 1 & 8 & 0 & 7 & 1 & 0 & 0 & 0 \\
\hline
\end{tabular}

* TK - technological knowledge, TPK - technological pedagogic knowledge, TPACK - technological, pedagogic and content knowledge. The numbers represent the number of different statements (different changes) for each category as expressed in the transcripts of the interviews.

Changes in the personal domain. Changes in the personal domain occurred in knowledge, beliefs, and attitudes. Changes in knowledge were reflected by an elaboration of the various knowledge bases included in the TPACK framework, as expressed in teachers' answers to the questionnaires and interviews.

Teachers' answers to the questionnaires show that they went through a change in their views of mobile technology as a tool for promoting teaching (TPK). Most of the teachers provided explanations for their willingness or decline to integrate technology in their teaching. These explanations were classified into two aspects: learning-related and technical-related explanations. Learning-related explanations emphasized the advancement of student learning (increase in innovation, interest and motivation, connection to the student's world, multiple teaching methods, and better demonstration). Technical aspects, on the other hand, included explanations that focused on availability of mobile devices, fear of discipline problems, and prohibiting use of smartphones at school, etc. The findings show a positive change in teachers' views, expressed as an increase in the percentage of learning-related explanations (and a decrease in technical-related explanations) in the second round of questionnaires (Table 5). Additionally, more learning-related explanations 
for integration of technology that were not mentioned in the first round of questionnaires (before the PD program) were mentioned in the second round (after the PD program had ended). We interpret this change as an indication of teachers' development of their TPK.

Table 5: Reasons for willingness/decline to integrate mobile technology in teaching as depicted in the pre and post questionnaires

\begin{tabular}{lll}
\hline Type of reasons & Before the PD program $(\mathbf{n}=\mathbf{2 0})$ & After the PD program $(\mathbf{n = 1 9})$ \\
\hline Technical-related & $45 \%$ of teachers & $5 \%$ of teachers \\
\hline Student learning-related & $35 \%$ of teachers & $63 \%$ of teachers
\end{tabular}

Of the 25 statements in teachers' answers to the post questionnaire, our analysis indicates that:

- $44 \%$ expressed pedagogical-technological knowledge (TPK)

- $41 \%$ expressed technological knowledge (TK)

- $15 \%$ expressed pedagogical knowledge (PK)

For example, teachers stated that they learned how the integration of collaborative documents allowed for tracking of the learning process, sharing between students and collaborative learning (TPK). They also got familiar with different programs and applications that they could incorporate in their teaching and acquired skills in editing Google forms (TK). Some teachers stated that they had learned about inquiry activities and the importance of collaborative learning (PK).

The nine teachers who were interviewed also referred to the advantages of the tools that they learned during the PD program for teaching, in general, and for teaching inquiry outdoors in particular. We interpreted these references as a development of TPK. For example, Alon explained how he perceives the potential of technology for promoting outdoor learning as follows:

[The students] share..., they work, they're with me, they don't just sit down and listen to me, they explore by themselves, they respond by themselves, they take notes by themselves, put up the data, add, take photos... they're more active. And that makes a big difference when working outdoors (Alon, interview1).

In addition, the teachers indicated, in the interviews, that they learned how to make changes in the technological environments that they experimented with (TK). Some, such as Adi, also showed pedagogical knowledge (PK) that they had acquired:

...I learned to emphasize and break down the tasks into small, structured stages so that students would be able to take this and work in the field. They will not even need me there to guide them (Adi, interview1).

In contrast, three of the teachers (Alon, Michael and Madi) felt that their skills in editing websites were still limited after the PD program, and argued that the reason for this was the little experience they got in the PD meetings (in one case, due to missing of a meeting).

The TPACK of six of the interviewed teachers was reflected in their description of activities they developed or plan to develop. These included explanations for the rationale for using the technological tools. For example, Avivit described how collaborative documents within an inquiry project could support learning:

I now want the students to put all of the data that they collected into the [collaborative] worksheet. This way I can see everything summarized, tidied... if they [the students] conduct collaborative activities, I don't need to keep checking my email ... I can comment [on the collaborative document] and return it to them, which is really excellent (Avivit, interview1). 
The changes in the attitudes and beliefs were reflected by self-efficacy and intentions for future integration of technology in teachers' practices. Analysis of the questionnaires showed an increase in willingness to integrate mobile technology in teaching from $85 \%$ of teachers at the beginning of the PD program (16 of the 20 responses) to $95 \%$ of teachers at the end of the PD program (18 of the 19 responses). In addition, all of the interviewees stated their intentions to integrate technology in their teaching in the future. Six of the teachers stated that their self-efficacy and confidence for integrating technology had increased. Nura, for example, stated:

I have learned... now I have more confidence to use it [technology]. I was familiar with [some of the technological tools] before, but haven't really used them. I was scared. But not anymore. Not like I was before the PD meetings (Nura, interview1).

Changes in the domain of practice. Changes in the domain of practice were expressed by:

a) experiencing design and development during the PD program, in the classroom and at home,

b) detailed descriptions of future activity, and

c) descriptions of integration of the technological tools in school practice.

While $95 \%$ (18 of the 19 responses) of the teachers incorporated the use of technology in their teaching prior to the PD program (as depicted from the pre-program questionnaire), their use of technology was primarily to assist students to consume information within the classroom, mostly using web 1.0 technologies. The devices they used included smart-boards, desktop computers connected to the internet, and a projector. Three teachers also stated the use of smartphones. Prior to the PD program, the teachers considered technology to be a tool primarily for visualization and for introducing or summarizing contents they taught (13 teachers). They did so by developing PowerPoint presentations and by projecting animations and videos they found on the Web (such as demonstration of experiments in YouTube) and having their students search for information as part of the inquiry process (10 teachers). Only two of the teachers stated that they used technology for communication with the students. This picture changed dramatically following the PD program. The interviews show that after the PD program teachers viewed students as collaborative knowledge builders and used much more web 2.0 technologies to support their students' learning. Adi, for example, described how Google documents enabled her to provide feedback to her students:

I asked each student to prepare [a Google document], and share it with me... I have one group in which students document all their work there [in a Google document]. They send me the link and I make my comments there. They also prepare tables [collaborative spreadsheets]... I can go in and have a look at their tables anytime (Adi, interview1).

Changes in the domain of consequence. Changes in the domain of consequence, according to Clarke and Hollingsworth's model (2002), are reflected in the practice outcomes that are perceived as salient to the teachers. Evidence for such changes came up in interviews and were related to teachers' enactment of the adapted learning environment with peers (teachers as mentors) or in cases in which teachers enacted the technological tools that they developed with their students. This evidence included:

a) teachers' insights concerning the quality of the activities that were developed (such as components that they felt that require additional refinement),

b) teachers' notions regarding pedagogical characteristics of their students' learning (such as collaborative learning supported by the activities they developed), and

c) teachers' notion of their students' emotional responses (such as enthusiasm). 
The teachers' change sequences. The analysis of teachers' change sequences, as reflected from the interviews, indicates a range of sequences, the salient ones being:

a) reflective processes stemming from the participation in the PD program (the external domain) and affecting the personal domain (32\% of all sequences identified),

b) reflective processes stemming from the professional experimentation (the domain of practice) and affecting the personal domain (24\%), and

c) enactment processes stemming from a change in the personal domain and affecting the domain of practice $(20 \%)$.

Examples of the analysis of the sequences are introduced in Table 6.

Table 6: Examples of the analysis of statements from interviews according to Clarke and Hollingsworth's (2002) notion of change sequences

\begin{tabular}{lll}
\hline $\begin{array}{l}\text { The change sequence } \\
\text { (from one domain to }\end{array}$ & $\begin{array}{l}\text { description of the } \\
\text { process }\end{array}$ & Example \\
another, with "enact- & \\
ment" or "reflection" as & \\
connecting process) &
\end{tabular}

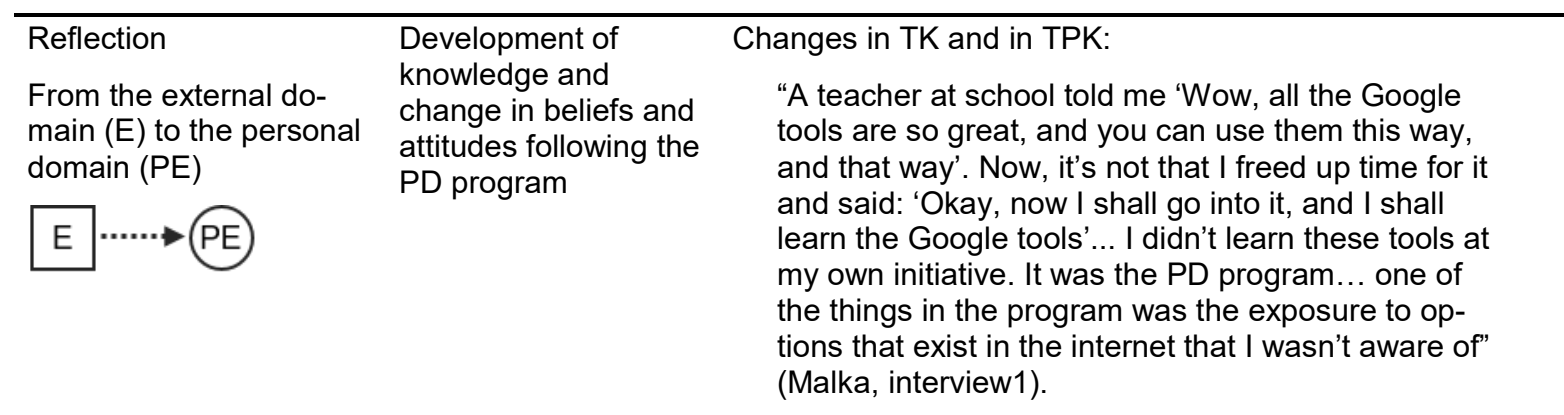

\begin{tabular}{ll}
\hline Reflection & $\begin{array}{l}\text { Development of } \\
\text { knowledge and } \\
\text { change in beliefs and } \\
\text { attitudes following the } \\
\text { practice (PR) to the per- } \\
\text { sonal domain (PE) }\end{array}$ \\
experiences during \\
and after the PD pro- \\
gram
\end{tabular}

A change in the sense of self-efficacy following the PD program and its experiences:

"This is the first time that I have used Google Drive [as an editor], to create forms. In the past, people would have sent me such forms [to fill in details]. But until now, it looked like something that is way beyond my skills. Now I think that it's easy for me to do it (Nihal, interview1).

\begin{tabular}{|c|c|c|}
\hline Enactment & \multirow{3}{*}{$\begin{array}{l}\text { Application of new } \\
\text { knowledge in practice } \\
\text { and change in atti- } \\
\text { tudes and beliefs that } \\
\text { affect practice }\end{array}$} & Application of TPK in teaching in the classroom: \\
\hline $\begin{array}{l}\text { From the personal do- } \\
\text { main }(P E) \text { to the domain } \\
\text { of practice (PR) }\end{array}$ & & $\begin{array}{l}\text { "After the second meeting [of the PD program] I } \\
\text { said to my students: 'Alright, you write the results } \\
\text { for me on Google Docs'... I knew Google Docs be }\end{array}$ \\
\hline & & $\begin{array}{l}\text { fore that. I used it in the past. But I had never en- } \\
\text { acted it with students" (Adi, interview1). }\end{array}$ \\
\hline
\end{tabular}

- external domain, $\bigcirc$ - internal domain, $\longrightarrow$ - enactment, $--\rightarrow$ - reflection.

\section{Professional growth processes}

The change sequences that five of the interviewees underwent could be interpreted as growth networks (viewed by Clarke and Hollingsworth (2002) as change sequences that persist in the long term). These teachers described how the PD program made them expand their knowledge through the experiences they went through and reported on changes that continued into their school practice too. An example of a professional growth network described in Figure 7 came up in the interview with Sama. Sama described how following her engagement in the PD program 
she learned to edit Google documents and Google sites (change in the personal domain) and created a website for her students that consisted of collaborative slides (change in practice). These slides allowed her to track students and identify collaborative learning through discussions that they held as part of the process (change in the domain of consequence) and also to provide them with formative feedback (change in practice). This experience provided her with concrete examples and led her to recognize the advantages of technology in advancing collaborative learning (change in the personal domain).

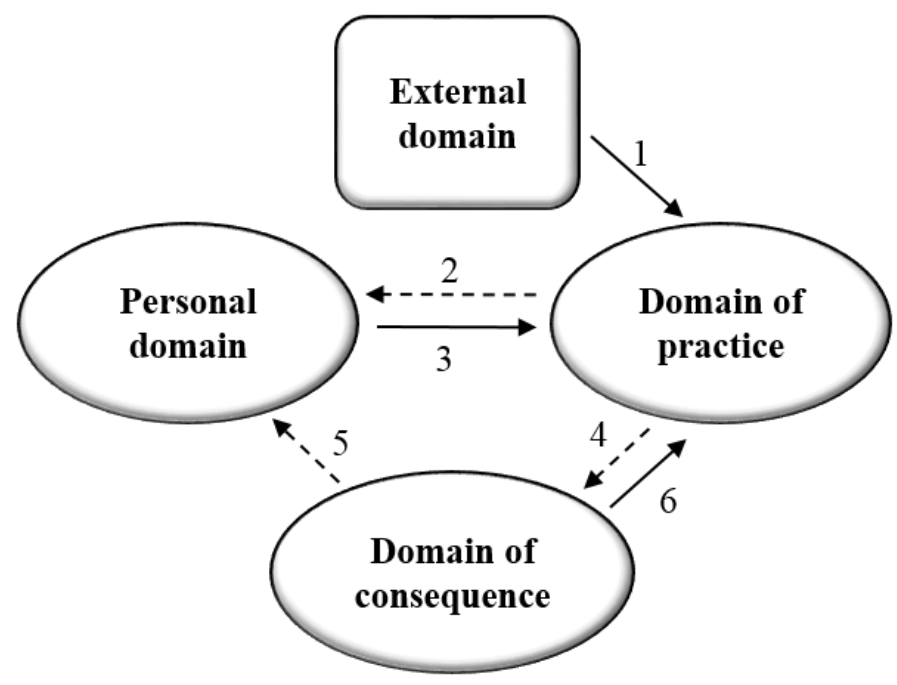

Figure 7: Sama's growth network

The second round of interviews enabled us to examine whether the growth networks that had been identified in the first round of interviews were sustained when checked about half a year later. The analysis indicated that five teachers (out of the seven interviewees in this round) who described future activities in the first interview (see Table 4) did continue to incorporate the technology in their teaching. For example, Sama created a collaborative document with a table in which students were required to fill in their row, with a picture of an organism of their choice, and a description of the organism's adaptation to a scarce water habitat (such as a cactus or a camel in the desert). Malka created collaborative presentations in which each student created a number of slides describing a different habitat. Adi used collaborative documents as a tool for preparation for an oral test on the group's outdoor inquiry project. Each student was requested to answer questions, individually in his/her own collaborative document, and provide feedback on the answers of another student in his group using the document. At the last stage, each group opened one collaborative document, in which the group members drafted together one answer for each of the questions.

\section{Discussion and Conclusions}

The literature describes a variety of challenges teachers face when teaching inquiry in the outdoors (e.g., Osborne, 2014; Tal \& Argaman, 2005) and demonstrates ways in which technology may support outdoor inquiry (e.g., Land \& Zimmerman, 2015). In this study, we implemented the Teachers-as-Designers approach by involving teachers in the design and development of technology-enhanced outdoor inquiry learning environments. The model of the PD program included three main stages: Teachers as learners, teachers as designers, and teachers as mentors. We examined how the unique design of the PD program contributed to the teachers' professional 
growth. Our findings show that this model proved to be effective as a way to support teacher professional growth, allowing the teachers to implement what they learned in their daily practice.

We assumed, as shown in our conjecture map, that a PD program that would integrate the current state of theoretical and practical knowledge regarding TaD, Mobile learning, and outdoor inquiry would lead to professional change processes among teachers and eventually to their professional growth. Specifically, we used mobile and non-mobile technology to streamline the learning between the various physical settings (as in Kali, Sagy et al., 2015) according to the model of outdoor inquiry learning (Orion, 1993, Tal et. al, 2014) and implemented the TaD approach (Svihla et al., 2015) with studio pedagogies (Crowther, 2013). The analysis of the data, inspired by the Interconnected Model of Professional Growth (Clarke \& Hollingsworth, 2002), enabled us to identify the professional change and growth processes following the PD program. This analysis affirmed the design conjecture. The findings showed that the PD program supported all of the teachers to undergo professional change processes that included changes in different degrees and diverse development trajectories. All the teachers showed change processes in the personal domain and in the domain of practice, and some in the domain of consequence as well. In the personal domain, the PD program exposed the teachers to technological tools and enabled them to develop TK and TPK that would further assist them in coping with challenges in outdoor inquiry teaching. As described in previous studies that dealt with involving teachers in the design of technology-enhanced curriculum materials (e.g., Koehler \& Mishra, 2005), some of the teachers also developed knowledge at the TPACK level (the highest level in the TPACK framework). In addition to the development of knowledge, the participation in the PD program resulted in changes in teachers' beliefs and attitudes, which was manifested in increased willingness to incorporate technology in their teaching and in their self-confidence to do so in practice.

The participation in the design process led also to changes in teachers' domain of practice. Some of the teachers demonstrated changes in their practice even months after the PD program has ended, as was evident in interviews, by their description of the way they integrated technology in their daily practice at school following the PD program. It seems that the teachers' experiences within the PD program as designers of TEL environments were significant for their professional growth. This was interpreted from the emphases that teachers gave in the interviews to the experience they had in designing and enacting their own learning environments (such as the statements cited in Table 6).

Some of the teachers also described changes in the domain of consequence following their integration of TEL materials that they had developed. These changes were reflected in teachers' insights concerning the quality of the adapted learning environments and the attention they gave to affective aspects of the students, which were revealed as a result of the new practice. These changes also contributed to teachers' willingness and motivation to continue to integrate the technology (as demonstrated in the description of Sama's professional growth).

In the design of the PD program, we applied recommendations from research literature regarding successful PD components (Loucks-Horsley et al., 2003; Penuel et al., 2007) and showed how teachers can be supported in designing technology-enhanced outdoor inquiry. The scaffolds that we designed implement the "fingerprint pattern of supports" described by Svihla et al. (2015) to support these processes in the following manner:

- modeling of practice - the teachers first experience, as learners, the use of the outdoor learning module which was designed by us as a model for their further adaptation,

- support for discourse - was implemented using the various activities for collaborative design, and

- design for real world use - was implemented by having teachers make the adaptations of their learning environments for their own students. 
The analysis of the development processes that the teachers had undergone, as reflected in the interviews, shows that the changes in the practice domain were most dominant, as reflected by the high percentage of change processes in this domain. Our findings show that the process of adaptation of a learning environment had provided teachers with a meaningful experience in pedagogical design. As emphasized by Salomon \& Ben-Zvi (2006), such an experience can provide teachers with much more than programs that focus on familiarization with technological tools.

The findings of this study also support the theoretical conjecture that we suggested in our conjecture map: teachers who went through a range of change processes in the three internal domains (personal, practice, and consequence) demonstrated the highest level of professional growth with long term effects. These findings differ from earlier notions regarding the need for continuous support in order for long term effects to occur (Dori \& Herscovitz, 2005). Teachers in the current study continued to integrate technology in other contexts, long after the PD program was over. They did so using the approaches they learned in the program although this was a relatively short (14 hour) intervention, which did not include additional follow-up support.

In addition to findings that confirm our conjectures, there were other findings that we will take into considerations in future changes to the design of the PD program. Firstly, not all of the teachers were involved in conducting high-level adaptations. Secondly, the analysis of the adapted learning environments of the teams showed that the coherence of the learning environments had decreased in comparison with the original outdoor learning module that we offered. Such learning environments, when used by students, may inhibit their development of sound scientific knowledge (Fortus \& Krajcik, 2012; Kali et al., 2008). Therefore, it seems that future research will need to develop and explore improved means to support teachers in adapting learning environments while maintaining a high level of coherence. Specifically, more research is needed to find ways to assist teachers in better exploiting the opportunities provided by the mobile technology to bridge between physical settings. Davis and Varma (2008) state that there is a risk of impaired coherence of curriculum materials when teachers make adaptations. In our case too, the reason for impaired coherence may be due to the fact that the teachers had received a copy of a whole inquiry module for adaptation. Thus, in the next iteration, we will enable greater freedom to the teachers in the design of the learning environment by providing a more open-ended learning environment (but with some scaffolding structure). In addition, as suggested by Davis and Varma (2008), we intend to add guided activities in which teachers will analyze the outdoor learning module that they have used as learners, before the adaptation stage. By doing so we hope to increase teachers' awareness of the importance of streamlining knowledge throughout the learning process and to improve the quality and coherence of the adapted learning environments. We also expect that this will allow for greater involvement of teachers in the design process, and consequently, will deepen their development and growth processes.

In conclusion, we have shown how the "TaD of TEL" approach can be implemented to support teachers' design of technology-enhanced outdoor inquiry activities. The three-stage model that we have developed - teachers as learners, teachers as designers, and teachers as mentors proved to support teachers' professional growth and adoption of advanced means for using technology, which can address some of the challenges inherent to outdoor inquiry teaching. We suggest using this model for additional PD contexts in which integration of technology has a potential to advance teaching and learning. Since teachers' involvement in design and development of technology-enhanced learning materials is crucial for the success of their implementation, we see great promise in our model as a way to promote productive use of technology by teachers, as well as long-term teacher professional growth. 


\section{Acknowledgement}

This research was supported by the I-CORE Program of the Planning and Budgeting Committee and The Israel Science Foundation grant 1716/12.

We would also like to thank Dr. Irit Sade, the head of the Environmental Science teaching program in the Israeli Ministry of Education, who promoted the PD program and enabled this research to be conducted.

\section{References}

Anastopoulou, S., Sharples, M., Ainsworth, S., Crook, C., Malley, C. O., \& Wright, M. (2012). Creating personal meaning through technology-supported science inquiry learning across formal and informal. International Journal of Science Education, 34(2), 251-273.

Barab, S., \& Squire, K. (2004). Design-based research: Putting a stake in the ground. The Journal of the Learning Sciences, 13(1), 1-14.

Bielaczyc, K. (2006). Designing social infrastructure: Critical issues in creating learning environments with technology. The Journal of the Learning Sciences, 15(3), 301-329.

Cahill, C., Lo, W. T., Kuhn, A., Quintana, C., McNally, B., Schmoll, S., \& Krajcik, J. (2011). Student use of multimodal data and metadata tools during nomadic inquiry. Proceedings of mLearn - 10th World Conference on Mobile Contextual Learning, Beijing, China.

Chi, M. T. (1997). Quantifying qualitative analyses of verbal data: A practical guide. The Journal of the Learning Sciences, 6(3), 271-315.

Clarke, D., \& Hollingsworth, H. (2002). Elaborating a model of teacher professional growth. Teaching and Teacher Education, 18(8), 947-967.

Cormode, G., \& Krishnamurthy, B. (2008). Key differences between Web 1.0 and Web 2.0. First Monday, 13(6). Retrieved from http://www.ojphi.org/ojs/index.php/fm/article/view/2125/1972

Crawford, B. A. (2000). Embracing the essence of inquiry: New roles for science teachers. Journal of Research in Science Teaching, 37(9), 916-937.

Crawford, B. A. (2014). From inquiry to scientific practices in the science classroom. In N. G. Lederman, \& S. K. Abell (Eds.), Handbook of research in science education (pp. 515-541). NY: Routledge.

Crowther, P. (2013). Understanding the signature pedagogy of the design studio and the opportunities for its technological enhancement. Journal of Learning Design, 6(3), 18-28.

Cviko, A., McKenney, S., \& Voogt, J. (2014). Teacher roles in designing technology-rich learning activities for early literacy: A cross-case analysis. Computers and Education, 72, 68-79. doi:10.1016/j.compedu.2013.10.014

Davis, E. A., \& Varma, K. (2008). Supporting teachers in productive adaptation. In Y. Kali, M. C. Linn, M. Koppal, \& J. E. Roseman (Eds.), Designing coherent science education: Implications for curriculum, instruction, and policy (pp. 94-122). NY: Teachers College Press.

Dillon, J., Rickinson, M., Teamey, K., Morris, M., Choi, M. Y., Sanders, D., \& Benefield, P. (2006). The value of outdoor learning: Evidence from research in the UK and elsewhere. School Science Review, 87(320), 107.

Dori, Y. J., \& Herscovitz, O. (2005). Case-based long-term professional development of science teachers. International Journal of Science Education, 27(12), 1413-1446.

Ercikan, K., \& Roth, W. M. (2006). What good is polarizing research into qualitative and quantitative? Educational Researcher, 35(5), 14-23. doi:10.3102/0013189X035005014

Fortus, D., \& Krajcik, J. (2012). Curriculum coherence and learning progressions. Second international handbook of science education (pp. 783-798) Springer. 
Gerard, L. F., Spitulnik, M., \& Linn, M. C. (2010). Teacher use of evidence to customize inquiry science instruction. Journal of Research in Science Teaching, 47(9), 1037-1063.

Johnson, R. B., \& Onwuegbuzie, A. J. (2009). Mixed methods research : A research paradigm whose time has come. Educational Researcher, 33(7), 14-26. doi:10.3102/0013189X033007014

Kali, Y. (2008). The Design Principles Database as means for promoting design-based research. In A. E. Kelly \& R. Lesh (Eds.), Handbook of design research methods in education: Innovations in science, technology, engineering, and mathematics learning and teaching (pp. 423-438). Mahwah, NJ: Lawrence Erlbaum Associates.

Kali, Y., \& Linn, M. C. (2007). Technology-enhanced support strategies for inquiry learning. In J. M. Spector, M. D. Merrill, J. J. G. V. Merriënboer, \& M. P. Driscoll (Eds.), Handbook of research on educational communications and technology (Vol. 3, pp. 145-161). Mahwah, NJ: Erlbaum.

Kali, Y., Linn, M. C., \& Roseman, J. E. (2008). Designing coherent science education: Implications for curriculum, instruction, and policy. NY: Teachers College Press. doi:10.1016/j.cpcardiol.2011.11.003

Kali, Y., McKenney, S., \& Sagy, O. (2015). Teachers as designers of technology enhanced learning. Instructional Science, 43(2), 173-179. doi:10.1007/s11251-014-9343-4

Kali, Y., \& Ronen-Fuhrmann, T. (2011). Teaching to design educational technologies. International Journal of Learning Technology, 6(1), 4-23.

Kali, Y., Sagy, O., Kuflik, T., Mogilevsky, O., \& Maayan-Fanar, E. (2015). Harnessing technology for promoting undergraduate art education: A novel model that streamlines learning between classroom, museum and home. IEEE Transactions on Learning Technologies, 8(1), 5 - 17.

Kali, Y., Tabak, I., Ben-Zvi, D., Kidron, A., Amzalag, M., Baram-Tsabari, A., ... Kirschner, P. (2015). Technology-enhanced learning communities on a continuum between ambient to designed: What can we learn by synthesizing multiple research perspectives? In O. Linkwall, P. Hakkinen, T. Koschmenn, P. Tchounikine, \& S. Ludvigsen (Eds.). Exploring the material conditions of learning: Proceedings of the computer supported collaborative learning (CSCL) conference, Gothenburg 2015. Vol. 2, (pp.615622). Retrieved from http://www.isls.org/cscl2015/papers/CSCL2015ProceedingsVolume2.pdf

Koehler, M. J., \& Mishra, P. (2005). What happens when teachers design educational technology? The development of technological pedagogical content knowledge. Journal of Educational Computing Research, 32(2), 131-152.

Land, S. M., \& Zimmerman, H. T. (2015). Socio-technical dimensions of an outdoor mobile learning environment: A three-phase design-based research investigation. Educational Technology Research and Development, 63(2), 229-255. doi:10.1007/s11423-015-9369-6

Lavie Alon, N., \& Tal, T. (2015). Student self-reported learning outcomes of field trips: The pedagogical impact. International Journal of Science Education, 37(8), 1-20. doi:10.1080/09500693.2015.1034797

Levy, K. S., Tal, T., \& Kali, Y. (2013). Supporting inquiry learning in the outdoors by mobile technology (in Hebrew). Paper presented at the Annual Conference for Science \& Environment, Rehovot, Israel.

Looi, C. K., Zhang, B., Chen, W., Seow, P., Chia, G., Norris, C., \& Soloway, E. (2011). 1:1 mobile inquiry learning experience for primary science students: A study of learning effectiveness. Journal of Computer Assisted Learning, 27(3), 269-287. doi:10.1111/j.1365-2729.2010.00390.x

Loucks-Horsley, S., Love, N., Stiles, K. E., Mundry, S. E., \& Hewson, P. W. (2003). Designing professional development for teachers of science and mathematics (2nd ed.). Thousand Oaks, CA: Corwin Press.

Laurillard, D. (2012). Teaching as a design science: Building pedagogical patterns for learning and technology. London: Routledge, Taylor \& Francis Group.

Mishra, P., \& Koehler, M. (2006). Technological pedagogical content knowledge: A framework for teacher knowledge. The Teachers College Record, 108(6), 1017-1054. 
Morag, O., \& Tal, T. (2012). Assessing learning in the outdoors with the field trip in natural environments (FiNE) framework. International Journal of Science Education, 34(5), 745-777. doi:10.1080/09500693.2011.599046

NRC. (2012). A framework for K-12 science education: Practices, crosscutting concepts, and core ideas. Committee on a Conceptual Framework for New K-12 Science Education Standards. Board on Science Education, Division of Behavioral and Social Sciences and Education. Washington, DC: The National Academies Press.

Orion, N. (1993). A model for the development and implementation of field trips as an integral part of the science curriculum. School Science and Mathematics, 93(6), 325-331. doi:10.1111/j.19498594.1993.tb12254.x

Orion, N., \& Hofstein, A. (1994). Factors that influence learning during a scientific field trip in a natural environment. Journal of Research in Science Teaching, 31(10), 1097-1119.

Osborne, J. (2014). Scientific practices and inquiry in the science classroom. In N. G. Lederman, \& S. K. Abell (Eds.), Handbook of research in science education, volume 2 (pp. 579-599). NY: Routledge.

Penuel, W. R., Fishman, B. J., Yamaguchi, R., \& Gallagher, L. P. (2007). What makes professional development effective? Strategies that foster curriculum implementation. American Educational Research Journal, 44(4), 921-958.

Reiser, B., \& Tabak, I. (2014). Scaffolding. In R. K Sawyer (Ed.), Cambridge handbook of the learning sciences (2nd ed.) (pp. 168-226). New York: Cambridge University Press.

Salomon, G., \& Ben-Zvi, D. (2006). The difficult marriage between education and technology: Is the marriage doomed? In L. Verschaffel, F. Dochy, M. Boekaerts \& S. Vosniadou (Eds.), Instructional psychology: Past, present and future trends (essays in honor of Erik de Corte) (pp. 209-222). Amsterdam: Elsevier.

Sandoval, W. (2014). Conjecture mapping: An approach to systematic educational design research. Journal of the Learning Sciences, 23(1), 18-36.

Shamir-Inbal, T., Dayan, J., \& Kali, Y. (2009). Assimilating online technologies into school culture. Interdisciplinary Journal of E-Learning and Learning Objects, 5(1), 307-334. Retrieved from http://www.ijello.org/Volume5/IJELLOv5p307-334Samir-Inbal675.pdf

Sharples, M., Taylor, J., \& Vavoula, G. (2007). A theory of learning for the mobile age. In R. Andrews, \& C. Haythornthwaite (Eds.), The sage handbook of elearning research (pp. 221-247). London: Sage.

Shulman, L. S. (1986). Those who understand: Knowledge growth in teaching. Educational Researcher, 15(2), 4-14.

Svihla, V., Reeve, R., Sagy, O., \& Kali, Y. (2015). A fingerprint pattern of supports for teachers' designing of technology-enhanced learning. Instructional Science, 43(2), 283-307. doi:10.1007/s11251-0149342-5

Tal, T. (2001). Incorporating field trips as science learning environment enrichment-An interpretive study. Learning Environments Research, 4(1), 25-49.

Tal, T., \& Abramovitch, A. (2012). Activity and action: Bridging environmental sciences and environmental education. Research in Science Education, 43(4), 1-23. doi:10.1007/s11165-012-93279

Tal, T., \& Argaman, S. (2005). Characteristics and difficulties of teachers who mentor environmental inquiry projects. Research in Science Education, 35(4), 363-394. doi:10.1007/s11165-004-8163-y

Tal, T., Bamberger, Y., \& Morag, O. (2005). Guided school visits to natural history museums in Israel: Teachers' roles. Science Education, 89(6), 920-935.

Tal, T., Dori, Y. J., \& Keiny, S. (2001). Assessing conceptual change of teachers involved in STES education and curriculum devleopment - The STEMS project approach. International Journal of Science Education, 23(3), 247-262. doi:10.1080/095006901750066501 
Tal, T., Lavie Alon, N., \& Morag, O. (2014). Exemplary practices in field trips to natural environments. Journal of Research in Science Teaching, 51(4), 430-461. doi:10.1002/tea.21137

Vavoula, G., Sharples, M., Rudman, P., Meek, J., \& Lonsdale, P. (2009). Myartspace: Design and evaluation of support for learning with multimedia phones between classrooms and museums. Computers \& Education, 53(2), 286-299.

Voogt, J., Laferrière, T., Breuleux, A., Itow, R. C., Hickey, D. T., \& McKenney, S. (2015). Collaborative design as a form of professional development. Instructional Science, 43(2), 259-282.

Voogt, J., Westbroek, H., Handelzalts, A., Walraven, A., McKenney, S., Pieters, J., \& de Vries, B. (2011). Teacher learning in collaborative curriculum design. Teaching and Teacher Education, 27(8), 12351244.

Wee, B., Shepardson, D., Fast, J., \& Harbor, J. (2007). Teaching and learning about inquiry: Insights and challenges in professional development. Journal of Science Teacher Education, 18(1), 63-89. doi:10.1007/s10972-006-9031-6

Zion, M., Cohen, S., \& Amir, R. (2007). The spectrum of dynamic inquiry teaching practices. Research in Science Education, 37(4), 423-447.

\section{Biographies}

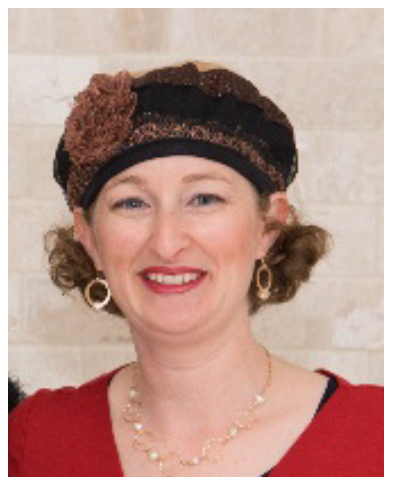

Keren-Sarah Levy completed her BA in molecular biochemistry and her MEd in biology education at the Technion - Israel Institute of Technology. She is currently a PhD student at the Faculty of Education in Science and Technology at the Technion. She studies how involvement of teachers in the design of technology-enhanced learning contributes to their professional development as mentors of inquiry in the outdoors. As a team member in centers for professional development in science teaching, she guides workshops and teacher professional programs, and designs technology-enhanced learning and teaching materials.

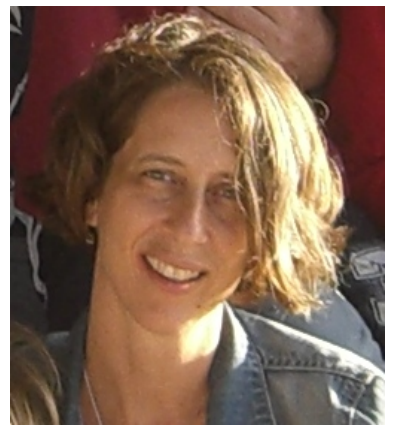

Yael Kali is an associate professor of technology-enhanced learning at the Technologies in Education Graduate Program, Faculty of Education, University of Haifa, and the director of the the Learning In a NetworKed Society (LINKS) Israeli Center of Research Excellence (ICORE). Using a design-based research approach, Kali explores technology-enhanced learning and teaching at various levels, from junior high school to higher education. Together with her students of the TEL Design group she studies the role of design, and design principles for supporting Computer Supported Collaborative Learning (CSCL), and for teacher professional development, in a Teachers as Designers (TaD) approach. Kali currently serves as an Associate Editor for the journal Instructional Science.

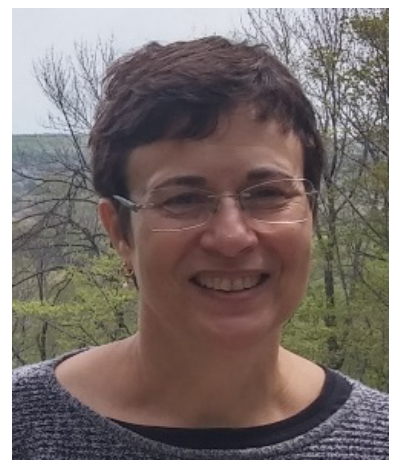

Tali Tal is an associate professor at the Faculty of Education in Science and Technology, Technion. Her research focuses on learning science in informal settings, inquiry-based learning, environmental education and learning with socio-scientific issues. Tali Tal has published in various research journals and book chapters that deal with her topics of interest. She is a board member of the Israel Society of Ecology and Environmental Sciences and the chair of the editorial board of "Ecology and Environment" an Israeli interdisciplinary peer review journal. 